\title{
The Workaholism Phenomenon in Portugal: Dimensions and Relations with Workplace Spirituality
}

\author{
Lisete S. Mónico $^{1, *}$ and Clara Margaça ${ }^{2}$ (D) \\ 1 Faculty of Psychology and Educational Sciences, University of Coimbra, 3000-115 Coimbra, Portugal \\ 2 Faculty of Psychology, University of Salamanca, 37005 Salamanca, Spain; claramargaca@usal.es \\ * Correspondence: lisete.monico@fpce.uc.pt
}

Citation: Mónico, Lisete S., and Clara Margaça. 2021. The Workaholism Phenomenon in Portugal: Dimensions and Relations with Workplace Spirituality. Religions 12: 852. https://doi.org/10.3390/ rel12100852

Academic Editors: Bernadette Flanagan and Noelia Molina

Received: 27 July 2021

Accepted: 20 September 2021

Published: 11 October 2021

Publisher's Note: MDPI stays neutral with regard to jurisdictional claims in published maps and institutional affiliations.

Copyright: (c) 2021 by the authors. Licensee MDPI, Basel, Switzerland. This article is an open access article distributed under the terms and conditions of the Creative Commons Attribution (CC BY) license (https:// creativecommons.org/licenses/by/ $4.0 /)$.

\begin{abstract}
Workaholism phenomenon affects a quarter of the employed world population. The concept has been used to describe hardworking employees, which is not resulting from external requirements. Considering that organizations with well-developed workplace spirituality have employees more committed to achieving self-development, but also to serve the company, the relationship between workaholism and workplace spirituality is not straightforward, remaining unclear. The principal aim of this research is to analyze the workaholism phenomenon, considering patterns of workaholic and non-workaholic workers and their relationships with dimensions of workplace spirituality. The sample is comprised of a heterogeneous group of 306 Portuguese employees, who were surveyed by the Workaholism Battery, five dimensions of Workplace Spirituality, and a sociodemographic questionnaire. Cluster analysis defined three workaholic profiles ( $24 \%$ of the sample), and five non-workaholic profiles. Workplace spirituality dimensions differed according to worker profile and associations with work involvement, work enjoyment, and compulsive work addiction. Enthusiastic addicts and work enthusiasts showed the highest workplace spirituality, contrasting mainly with Reluctant hard worker, Disenchanted workers, and Unengaged workers, but also with work addicts. Workaholism is a complex and multidimensional phenomenon, whose dimensions are distinctly related to workplace spirituality. Workplace spirituality development can promote a more balanced and healthy relationship with work.
\end{abstract}

Keywords: workaholism; workplace spirituality; worker profiles; Portuguese employees

\section{Introduction}

The workaholism phenomenon affects a quarter of the employed population and it is described as a tendency to be obsessed with work duties and to work excessively hard. Furthermore, an all-consuming devotion to work is related to a set of undesirable consequences. This concept has been used to describe hardworking employees, which is not resulting from external requirements. Workaholics have persistent thoughts about work, experience negative emotions when not working (Clark et al. 2020), feel compelled to work as addicted, being deprived of activities in other areas of life, including family and relationships. Several researches provide robust evidence that workaholism is an addiction to work that leads to many negative individual, interpersonal, and organizational outcomes (Clark et al. 2016), and is characterized by working excessively (Schaufeli et al. 2008). According to Balducci et al. (2020a), there is a certain consensus regarding the definition of workaholism: being obsessed with work, a significant psychological dysfunction characterized by an excessive concern with work, and an uncontrollable internal desire to invest too much in work activities.

In Portugal, in 2010, it was estimated that $10 \%$ of workers would be workaholics (Cristão 2010), a behavior that causes negative emotions (e.g., guilt, anxiety, disappointment) and unpleasant activated emotions (e.g., irritability, hostility). In addition, the compulsion to work hinders the psychological disconnection from work and can influence 
the individual's ability to recover negatively, which also has an impact on physical health (Ornek and Kolac 2020). In 2019, Forbes pointed out that $66 \%$ of millennials suffered from workaholism, a trend that has worsened with the pandemic that has plagued all corners of the world since the end of that year (Stahl 2019).

In the workplace, the experience of being connected to others and the community environmental work, as well as the recognition that employees have an inner life that nourishes and is nourished by significant work, where they endow their energy, is associated with workplace spirituality (Foster and Foster 2019). According to Bella et al. (2018), workplace spirituality facilitates the promotion of opportunities for personal growth and fulfillment, as well as opportunities for significant contribution to society. Thus, it allows meeting individuals' needs for inner life, purpose, and community, which translates into a more sustainable way of working and living. Considering that organizations with well-developed workplace spirituality have employees more committed to achieving self-development, but also to serve the company, the relationship between workaholism and workplace spirituality is not straightforward, remaining unclear.

As a result of Covid-19 pandemic, the limits between work and personal life have become a very tenuous line. This happens because working from home is ingrained into family life, which affects relationships, as well as physical and mental health. Globalized competition, characteristic of modern societies, contributes to perpetuating workaholic behavior, which is reflected in a long workday, reinforced by tangible (e.g., promotion) and intangible (e.g., compliment) rewards (Balducci et al. 2020a). Thus, workplace spirituality can be a key factor; it is a multidimensional construct and a positive means to improve the success and competitiveness of organizations, as well as employees' well-being. The promotion of the workplace spirituality dimension is related to more responsible and pro-social behaviors (Dhiman and Marques 2016). Bearing in mind that the workplace is considered an inseparable part of human life and a source of values in communities, organizations can be seen as spiritual entities (Fairholm 1996). In this way, and in line with the 2030 Agenda, it is possible to affirm that workplace spirituality contributes to sustainability, insofar as the inherent values (i.e., a sense of community, care for others and for nature) will influence the future generations (Afsar and Badir 2017; Rezapouraghdam et al. 2019). Hence, workplace spirituality can be a path to sustainable development.

The principal aim of this study is to analyze the workaholism phenomenon, considering patterns of workaholic and non-workaholic workers, and their relationships with dimensions of workplace spirituality.

\section{Background}

\subsection{Workaholism: Work Addicts or Work Engaged?}

Especially in Western countries, the world of work has undergone profound changes in the past forty years. Today's workers have no time to leave the office, work longer days, and still take work home (Aziz and Tronzo 2011). Oates (1971) refers that a workaholic is a person "whose need for work has become so excessive that it creates noticeable disturbance or interference with his bodily health, personal happiness, and interpersonal relations, and with his smooth social functioning" (p. 4). Spence and Robbins (1992) define this concept as a set of attitudes, classified into three components: work involvement (limits between work and personal life), drive (internal motivation), and enjoyment of work (satisfaction obtained with work). It is described as an internal motivation to become overly involved in work, ignoring other areas of daily life (Porter 1996); vicious behavior (Atroszko et al. 2019) that leads to mood swings, withdrawal symptoms, conflict (Griffiths 2005); behaviors that include: working on breaks and during meals, not being able to delegate work; or yet, according to $\mathrm{Ng}$ et al. (2007), it encompasses three dimensions-affective (enjoying the act of working), cognitive (obsessed with work), and behavioral (working more hours than is due).

Several studies pointed out that workaholism as being associated with worse general well-being indices (e.g., Balducci et al. 2018; Schaufeli et al. 2008), as well as worse physical 
and mental health, and is related to many negative outcomes, such as burnout, job stress, work-life conflict (e.g., Clark et al. 2016). Therefore, workaholism cannot be seen as a positive characteristic indicating a healthy passion and enthusiasm for one's work not even to be associated with higher job performance (Balducci et al. 2020b). But, rather, as an unhealthy characteristic of a vicious behavior that can have destructive consequences for the individual's emotional, social and physical well-being (Stoeber and Damian 2016). It is important to note that the concepts of workaholism and engagement at work are often confused. The main difference between both is related to motivation, the trigger of behaviors. Briefly, workaholics feel an internal compulsion to work, whereas engaged workers see the act of working as intrinsically pleasurable (Subramanian 2018).

It is important to highlight that, with the mandatory confinement caused by the Covid-19 pandemic, the forced work-at-home scenario may have caused an increase in the workaholism situation (Molino et al. 2020; Spagnoli and Molinaro 2020). If there are benefits (such as reduced travel time), the consequences include a blurred line between work and family, social isolation, employees bearing the costs (e.g., pay for the internet), and work more than the due time (Vyas and Butakhieo 2020).

\subsection{Spirituality: A Linkage between Workplace and Wellbeing}

Workplace Spirituality (WS) has been the subject of several studies in recent years as a prominent reality (Mónico et al. 2016). In a plural society, where tolerance and spiritual and cultural freedom are sought, is crucial a true understanding of the place of different religions and spiritualities in the organizational environment (Wall and Knights 2013). Several studies were reported WS as a necessary determinant of employee commitment, job satisfaction and work-life balance satisfaction (e.g., Garg 2017). Research conducted by Pawar (2016) highlights that WS has a positive relationship with emotional, psychological, social, and spiritual well-being. However, a study by Foster and Foster (2019) revealed that most employees considered that spirituality was not something they felt comfortable discussing or appropriate to practice in the workplace.

Spirituality is independent of any religion or belief system, considered as a complex, multi-cultural and multi-dimensional concept (Mónico et al. 2016; Zsolnai and Illes 2017), and possesses a social basis and a social dimension (Oman 2015). It refers to an inner experience of an individual and can also be understood as the capacity to find and construct meaning about life and existence and to move toward personal growth, responsibility, and relationship with others (Myers and Williard 2003).

Samah et al. (2012) highlight the role of the organization as fundamental in the development of the spiritual needs of its employees. A study conducted by Kolodinsky et al. (2008) highlighted that WS is positively related to involvement and job satisfaction, organizational identification, and negatively related to organizational frustration. Another study demonstrated that there is a positive correlation between psychological capital and workaholism, and both have positive and direct repercussion on WS (Pedreira and Mónico 2013). Spirituality, when integrated into the professional environment, can lead to a greater seek for fulfillment (Fry 2003), as well as the development of a sense of community, through a connection with something greater (Marques et al. 2005). In other words, spiritual individuals tend to consider their role in employment to be significant (Tepper 2003), as spirituality is related to the commitment to the organization, which triggers an increase in engagement (Pawar 2016), personal and positive values (Murray and Evers 2011), as loyalty to the organization (Rego and Cunha 2008). According to Roof (2015), spirituality can significantly affect engagement, which translates into a direct relationship between spirituality-engagement. Hence, the significant effort of an engaged employee reflects pleasure at work, unlike the workaholic who does it out of compulsion (Clark et al. 2020). Several studies (e.g., Rahman et al. 2019; van der Walt and Klerk 2014) highlighted that spirituality in the workplace triggers positive results for organizations because it is strongly associated with engagement at work. According to Duchon and Plowma (2005), these concepts are associated with the sense of fulfillment and completeness, 
allowing employees to express themselves as a whole and to feel safe psychologically in the workplace, synonymous of a significant motivational effect (Bickerton et al. 2015).

\section{Method}

\subsection{Participants}

The sample is comprised of a heterogeneous group of 306 Portuguese employees from a wide variety of jobs and Portuguese's enterprises. A diverse sample of respondents was intended, including both genders, different ages, professions and positions, experiences and work systems. Of these respondents, $55.9 \%$ were female and $44.1 \%$ were male, with an average age of 40.34 years, ( $S D=10.93$ ). Regarding education, $30.1 \%$ of participants completed basic education, $34.6 \%$ completed secondary education and $35.3 \%$ completed higher education. With regard to the professional situation of the respondents, the majority are employed $(56.9 \%)$, followed by State workers (20.6\%) and businesspersons (14.4). The rest fall into the categories of self-employed professionals (3.6\%) and student workers (4.6\%). It is important to highlight that $31.4 \%$ of the sample occupies some leadership position. With regard to the number of employees of the organization where the participants work, the majority $(35.0 \%)$ work in a company with a maximum of 10 employees or in companies with 11 to 50 employees (29.7\%). Participants have an average of 12 years of working time in the current organization. When analyzing the monthly net salary, almost half of the sample (45\%) earns between 501 and 1000 euros monthly; another half receives up to 500 euros $(20.9 \%)$ or between 1001 and 1500 euros (20.3\%). The remaining participants receive between 1501 and $2000(8.5 \%)$ and a salary above 2000 euros (4.9\%). Table 1 presents the sociodemographic characteristics of participants.

Table 1. Sociodemographic characterization of the sample $[N=306]$.

\begin{tabular}{|c|c|c|c|c|c|}
\hline & & \multicolumn{4}{|c|}{ Sample } \\
\hline & & $\mathbf{n}$ & $\%$ & $\mathbf{M}$ & SD \\
\hline \multirow[t]{2}{*}{ Gender } & Female & 171 & 55.9 & & \\
\hline & Male & 135 & 44.1 & & \\
\hline Age & (min 18, max 69 years-old) & & & 40.34 & 10.93 \\
\hline \multirow[t]{3}{*}{ Education } & Basic Education & 92 & 30.1 & & \\
\hline & Secondary Education & 106 & 34.6 & & \\
\hline & Higher Education & 108 & 35.3 & & \\
\hline \multirow{5}{*}{$\begin{array}{l}\text { Professional } \\
\text { Situation }\end{array}$} & Employed & 174 & 56.9 & & \\
\hline & State workers & 63 & 20.6 & & \\
\hline & Businesspersons & 44 & 14.4 & & \\
\hline & Self-employed & 11 & 3.6 & & \\
\hline & Student-workers & 14 & 4.6 & & \\
\hline \multirow{2}{*}{$\begin{array}{l}\text { Leadership } \\
\text { Position }\end{array}$} & Yes & 96 & 31.4 & & \\
\hline & No & 210 & 68.6 & & \\
\hline \multicolumn{4}{|c|}{ Stay in the organization $(\min 0, \max 56$ years) } & 12.09 & 10.50 \\
\hline \multirow{4}{*}{$\begin{array}{l}\mathrm{N}^{\mathrm{o}} \text { employees } \\
\text { per organization }\end{array}$} & Up to 10 & 107 & 35.0 & & \\
\hline & Between 11 and 50 & 91 & 29.7 & & \\
\hline & Between 51 and 200 & 42 & 13.7 & & \\
\hline & More than 200 & 66 & 21.6 & & \\
\hline \multirow[t]{5}{*}{ Net Salary } & Up to 500 euros & 64 & 20.9 & & \\
\hline & Between 501 and 1000 euros & 138 & 45.1 & & \\
\hline & Between 1001 and 1500 euros & 62 & 20.3 & & \\
\hline & Between 1501 and 2000 euros & 26 & 8.8 & & \\
\hline & More than 2000 euros & 16 & 4.9 & & \\
\hline
\end{tabular}




\subsection{Research Tools}

\subsubsection{The Workaholism Battery}

This battery (WorkBat), performed by Spence and Robbins (1992), is the widest instrument used in the investigation of workaholism, which is composed of different aspects of the relationship of employees with work and with the use of free time. The version adopted in this research was based on a standardized translation-back-translation procedure of the original by Andreassen et al. (2010). The whole questionnaire, composed of 25 items measured through a 5-point Likert scale (1-strongly disagree to 5-strongly agree), showed good reliability $(\alpha=0.80)$. Confirmatory factor analysis supports the trifactor model $(\mathrm{CMIN} / \mathrm{DF}=2.53, \mathrm{NFI}=0.68, \mathrm{RMSEA}=0.071$; one error term correlated between items belonging to the same factor, based on the highest modification indices): (F1) Work Involvement- the use of time and energy in or out of work (8 items; ex: "I feel guilty when I miss work"); (F2) Drive- the internal motivation of people to work, level of drive to work (7 items; ex: "I often feel that there is something inside me that makes me work"); and (F3) Enjoyment of Work-the level of pleasure from work obtained through responses (10 items; ex: "I work more than is waited for me closely for its fun").

\subsubsection{Workplace Spirituality Scale}

For the assessment of spirituality in workplace, it was adopted a 6-point Likert scale (1-This sentence is completely false to 6-This sentence is completely true) from Rego and Pina e Rego and Cunha (2008), composed of 17 items with excellent reliability ( $\alpha=0.93$ ). The second-order factor model showed an acceptable fit $(\mathrm{CMIN} / \mathrm{DF}=2.873, \mathrm{NFI}=0.91$, RMSEA $=0.078)$, composed of five dimensions: (F1) Team's sense of community-the sense of community and common purpose, team spirit and mutual care among members (5 items, $\alpha=0.93$; e.g., "People in my group/team feel part of a family"); (F2) Alignment between organizational and individual values - the compatibility of the individual's values and inner life with the organization's values, mission and purposes ( 5 items, $\alpha=0.88$; e.g., "I feel good about the values that prevail in my organization"); (F3) Sense of contribution to the community-the relationship between work and personal values ( 3 items, $\alpha=0.80$; e.g., "I see that there is a connection between my work and the benefits for society as a whole"); (F4) Sense of enjoyment at work-the sense of pleasure and enjoyment at work ( 2 items, $\alpha=0.78$; e.g., "I feel joy in my work"); and (F5) Opportunities for the inner life-the organization's respect to the individual's spiritual values and the spirituality of the workers ( 2 items, $\alpha=0.75$; e.g., (reversed item): "My spiritual values are not valued in my workplace").

\subsection{Procedure}

Data collection was carried out in person by a research team, in Portugal, including the Autonomous Regions of Madeira and Azores, before the pandemic period. This team was composed by students of the subject Methodology of Research in Psychology of the integrated master in Psychology of the University of Coimbra. All the formal and ethical procedures of data collection were respected. Information was given about the purpose of the study and how participants should respond, explaining to them that the participation was anonymous and data will be used exclusively for academic purposes, despite can be suspended at any time. Participants agreed to informed consent, with the guarantee of the protection of their data, which includes anonymity and confidentiality. The inclusion criteria to be in the sample was that the employees have at least six months of professional experience and are currently working. Therefore, the type of enterprise or business structure was not defined.

\subsection{Data Analysis}

The tabulating and data analysis were performed through the statistical programs SPSS and AMOS (IBM Corp 2013). Missing values (1.6\%) were replaced through series 
mean method Skewness and kurtosis values indicate a normal distribution, $\mid$ Sk $\mid<1.30$ and $|\mathrm{Ku}|<1.73$.

Reliability was calculated by Cronbach's alpha (Nunnally and Bernstein 1994). The score of 0.80 was taken as a good reliability indicator (Urbina 2014), and 0.70 as acceptable (Hair et al. 2018). Confirmatory factor analysis (CFA) was carried out with the maximum likelihood estimation method. Goodness of fit was analyzed using CMIN/DF (normed chi-square), NFI (normed fit index), and RMSEA (Root Mean Square Error of Approximation) (Kline 2011; Schumacker and Lomax 2016). Modification indices (MI) were used to determine how the fit of the model could be improved (Bollen 1989), and we considered freeing the parameters with higher MI inside each factor.

The predictive power of the dimensions was tested using hierarchical regression analysis. This method allows the researcher to enter independent variables cumulatively according to some specified hierarchy that is dictated in advance by the theory and logic of the research (Tabachnick and Fidell 2007). The assumptions of the hierarquical multiple regression were analyzed. Normal distribution and homogeneity were validated graphically. Independence of errors was obtained through the Durbin-Watson statistic, with scores between 0.92 and 1.28. The Variance Inflation Factor was used to diagnose multicollinearity, none of the variables being collinear (VIFs $<2.95)$.

After the descriptive statistics and intercorrelation matrix, two-step cluster analysis were performed with the WorkBat dimensions, leading to a classification of the participants into groups (low/high) in each dimension, and subsequently in the workaholic profiles. This is a hybrid approach that first uses a measure of distance to separate groups and after a probabilistic approach to choose the ideal subgroup (Kent et al. 2014). Using this technique allow to determine the number of clusters based on a statistical measure of fit, through the use of categorical and continuous variables simultaneously, analyzing the outliers (Kent et al. 2014). Several studies have proved this analysis to be one of the most reliable in terms of the number of subgroups detected, probability of classification of individuals into subgroups, and reproducibility of findings in clinical and other types of data (Gelbard et al. 2007; Kent et al. 2014). The distance measure was calculated by the Log-Likelihood method. The classification of clusters was done by using the Schwarz's Bayesian Criterion, which indicated for each dimension of WorkBat the number of clusters with good quality of discrimination (silhouette measure of cohesion and separation $>0.50$ ).

A Multivariate Analysis of Variance (MANOVA) was subsequently conducted to test whether the workaholic profiles differ from each other regarding workplace spirituality. The assumptions for the reliable use of this test (Hair et al. 2018) were analyzed. Pillai's Trace was used because it is a powerful statistic procedure and very robust to modest violations of normality and equality of the covariance and variance matrix, Box's M = 189.26 $\mathrm{F}(105,12261.67)=1.50, p=0.001$. Post-hoc Bonferroni tests for multiple comparisons were performed.

\section{Results}

Table 2 presents the descriptive and intercorrelations of workaholism and workplace spirituality. On average, participants scored $4.24(\mathrm{SD}=0.87)$ on the global workplace spirituality scale, slightly exceeding the midpoint of each scale, the same occurring for the three dimensions of the WorkBat. A correlation matrix was created to assess the levels of association among the variables. As displayed in Table 2, it is notable that the majority of the correlations were statistically significant, except for the correlations between Drive and TsenseCommunity $(r=0.071)$, the Involvement and oppInnerLife $(r=0.039)$, and between Drive and oppInnerLife $(r=-0.029)$. According to Cohen's classification (Cohen 1988), high correlations are greater than 0.50 , moderate correlations are between 0.30 and 0.50 , and low correlations of 0.10 and 0.30 and 0.10 a zero. It should be noted that the correlation between the global scales was positive and moderate $(r=0.40, p<0.01)$. 
Table 2. Descriptive statistics ( $\min , \max , \mathrm{M}, \mathrm{SD}$ ) and correlation matrix.

\begin{tabular}{|c|c|c|c|c|c|c|c|c|c|c|c|c|}
\hline & Min. & Max. & Mean & SD & 2 & 3 & 4 & 5 & 6 & 7 & 8 & 9 \\
\hline 1. WorkBat-Work Involvement & 2.25 & 5.00 & 3.42 & 0.54 & $0.342^{* *}$ & $0.277^{* *}$ & $0.165^{* *}$ & $0.115^{*}$ & $0.175^{* *}$ & $0.173^{* *}$ & $0.128 *$ & 0.039 \\
\hline 2. WorkBat-Drive & 1.14 & 5.00 & 3.15 & 0.66 & 1 & $0.274 * *$ & $0.131 *$ & 0.071 & $0.180 * *$ & $0.148^{* *}$ & $0.115 *$ & -0.029 \\
\hline 3. WorkBat-Enjoyment of work & 1.10 & 5.00 & 3.02 & 0.64 & & 1 & $0.496^{* *}$ & $0.376^{* *}$ & $0.402^{* *}$ & $0.441^{* *}$ & $0.594^{* *}$ & $0.230 * *$ \\
\hline 5. WS_TsenseCommunity ${ }^{\mathrm{ii}}$ & 1.00 & 6.00 & 4.11 & 1.09 & & & & 1 & $0.730^{* *}$ & $0.440 * *$ & $0.595^{* *}$ & $0.419^{* *}$ \\
\hline 6. WS_Aligment ${ }^{\mathrm{iii}}$ & 1.00 & 6.00 & 4.12 & 1.02 & & & & & 1 & $0.592 * *$ & 0.652 ** & $0.416^{* *}$ \\
\hline 7. WS_senContribComun ${ }^{\text {iv }}$ & 1.00 & 6.00 & 4.51 & 1.05 & & & & & & 1 & $0.646^{* *}$ & $0.228^{* *}$ \\
\hline 8. WS_senseJoyment ${ }^{\mathrm{v}}$ & 1.00 & 6.00 & 4.5 & 1.02 & & & & & & & 1 & $0.344^{* *}$ \\
\hline
\end{tabular}

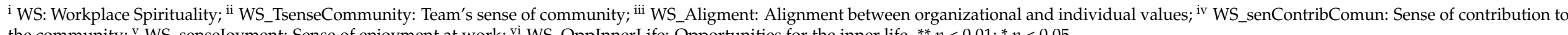

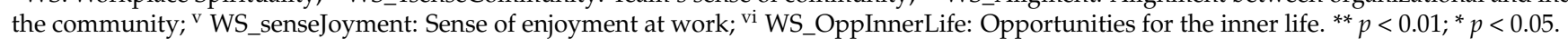


To understand whether the workaholism dimensions can be predicted from the dimensions of workplace spirituality, it was conducted a hierarchical multiple regression (Table 3), controlling variables such as gender, age, education, stay in the organization, and a leadership role in the organization. This analysis allowed testing which dimensions of workplace spirituality had an effect on workaholism.

Table 3. Hierarchical Multiple Regression of dimensions of workaholism predicted by workplace spirituality.

\begin{tabular}{|c|c|c|c|c|c|c|c|c|}
\hline${ }^{*}$ DV: Work Involvement & $\mathbf{R}$ & $\mathbf{R}^{2}$ & $\mathbf{R}^{2}{ }_{\text {adj }}$ & $\Delta \mathrm{R}^{2}$ & $\mathbf{b}$ & SE & B & $\mathbf{t}$ \\
\hline & 0.272 & 0.074 & 0.043 & 0.035 & & & & \\
\hline Gender $(1=$ male $; 2$ = female $)$ & & & & & -0.08 & 0.06 & -0.07 & -1.22 \\
\hline Age (years) & & & & & 0.00 & 0.00 & -0.08 & -0.98 \\
\hline Education (years) & & & & & 0.00 & 0.01 & -0.01 & -0.09 \\
\hline Leadership role $(1=$ yes; $0=$ no $)$ & & & & & 0.18 & 0.07 & 0.16 & 2.54 * \\
\hline Stay in the organization (years) & & & & & 0.00 & 0.00 & -0.02 & -0.31 \\
\hline WS_senseCommunity & & & & & -0.02 & 0.04 & -0.03 & -0.39 \\
\hline WS_Aligment & & & & & 0.06 & 0.05 & 0.12 & 1.24 \\
\hline WS_senContribComun & & & & & 0.07 & 0.04 & 0.14 & 1.71 \\
\hline WS_senseJoyment & & & & & 0.00 & 0.05 & -0.01 & -0.08 \\
\hline WS_OppInnerLife & & & & & -0.02 & 0.03 & -0.05 & -0.74 \\
\hline${ }^{*}$ DV: Drive & 0.286 & 0.082 & 0.050 & 0.044 & & & & \\
\hline Gender ( 1 = male; 2 = female $)$ & & & & & 0.05 & 0.08 & 0.04 & 0.67 \\
\hline Age (years) & & & & & -0.01 & 0.00 & -0.11 & -1.36 \\
\hline Education (years) & & & & & -0.01 & 0.02 & -0.04 & -0.67 \\
\hline Leadership role $(1=$ yes; $0=$ no $)$ & & & & & 0.23 & 0.09 & 0.17 & $2.69 * *$ \\
\hline Stay in the organization (years) & & & & & 0.00 & 0.00 & 0.08 & 0.97 \\
\hline WS_TsenseCommunity & & & & & -0.09 & 0.05 & -0.14 & -1.66 \\
\hline WS_Aligment & & & & & 0.15 & 0.06 & 0.24 & $2.49 *$ \\
\hline WS_senContribComun & & & & & 0.04 & 0.05 & 0.06 & 0.73 \\
\hline WS_senseJoyment & & & & & 0.02 & 0.05 & 0.03 & 0.38 \\
\hline WS_OppInnerLife & & & & & -0.06 & 0.03 & -0.11 & -1.70 \\
\hline *DV: Enjoyment of work & 0.634 & 0.402 & 0.382 & 0.349 & & & & \\
\hline Gender ( $1=$ male; 2 = female $)$ & & & & & -0.01 & 0.06 & -0.01 & -0.14 \\
\hline Age (years) & & & & & -0.01 & 0.00 & -0.16 & $-2.36^{*}$ \\
\hline Education (years) & & & & & 0.03 & 0.01 & 0.11 & $2.30 *$ \\
\hline Leadership role $(1=$ yes; $0=$ no $)$ & & & & & 0.15 & 0.07 & 0.11 & $2.27 *$ \\
\hline Stay in the organization (years) & & & & & 0.00 & 0.00 & 0.06 & 1.00 \\
\hline WS_TsenseCommunity & & & & & 0.01 & 0.04 & 0.02 & 0.23 \\
\hline WS_Aligment & & & & & -0.02 & 0.05 & -0.03 & -0.34 \\
\hline WS_senContribComun & & & & & 0.08 & 0.04 & 0.12 & 1.94 \\
\hline WS_senseJoyment & & & & & 0.33 & 0.04 & 0.52 & $7.61^{* * *}$ \\
\hline WS_OppInnerLife & & & & & -0.01 & 0.03 & -0.01 & -0.25 \\
\hline
\end{tabular}

${ }^{*}$ DV: Dependent Variable; ${ }^{* * *} p<0.001 ;{ }^{* *} p<0.01 ;{ }^{*} p<0.05$.

After statistical control of sociodemographic variables, it was possible to observe that not all the workplace spirituality' dimensions had the same importance in increasing workaholism' components. Regarding the shared variance of the dependent variable (R2), the predictors of this model explain $7.4 \%$ of Involvement, $8.2 \%$ of Drive, and $40.2 \%$ of Pleasure.

Considering control variables, only leadership role was a significant positive predictor of Involvement, Drive, and Enjoyment of work, with higher scores in these WorkBat dimensions estimated for individuals occupying a leadership position (e.g., director, CEO, manager, department responsible, etc.). For the dimension Drive, only leadership role and Alignment factor had a significant and positive prediction. Finally, for the third dimension of the workaholism (Enjoyment of work), it was possible to found age as a negative predictor, but also three positive and significant predictors: education, leadership role, and Sense of enjoyment at work. 


\section{Definition of Profiles of Workers}

Each dimension of the Workaholism Battery was individually submitted to cluster analysis. Two clusters were obtained for Involvement, Drive, and Enjoyment of work, with good quality of discrimination (see Table 4).

Table 4. Number of clusters, quality of discrimination, number of participants in each cluster $(n, \%)$ and means (M) for the dimensions of the Workaholism Battery.

\begin{tabular}{|c|c|c|c|c|c|c|}
\hline \multirow{2}{*}{$\begin{array}{c}\text { WorkBat } \\
\text { Dimensions: }\end{array}$} & \multirow[t]{2}{*}{ Number of Clusters (C) } & \multirow[t]{2}{*}{ Quality of Discrimination } & \multicolumn{2}{|c|}{ C1-Low } & \multicolumn{2}{|c|}{ C2-High } \\
\hline & & & $\%(n)$ & $M$ & $\%(n)$ & $M$ \\
\hline $\begin{array}{c}\text { Work } \\
\text { Involvement }\end{array}$ & 2 & 0.7 & $\begin{array}{c}63.7 \% \\
(n=195)\end{array}$ & 3.09 & $\begin{array}{c}36.3 \% \\
(n=111)\end{array}$ & 4.00 \\
\hline Drive & 2 & 0.7 & $\begin{array}{c}65.4 \% \\
(n=200)\end{array}$ & 2.78 & $\begin{array}{c}34.6 \% \\
(n=106)\end{array}$ & 3.86 \\
\hline $\begin{array}{l}\text { Enjoyment of } \\
\text { work }\end{array}$ & 2 & 0.7 & $\begin{array}{c}68.0 \% \\
(n=208)\end{array}$ & 2.68 & $\begin{array}{c}32.0 \% \\
(n=281)\end{array}$ & 3.73 \\
\hline
\end{tabular}

The joining of the participants' belonging to each of the clusters in the three dimensions of WorkBat led to the emergence of eight different profiles of workers, three representing workaholic profiles and five non-workaholic profiles:

Enthusiastic Addicts-They report high scores in the three dimensions of the workaholism scale (Spence and Robbins 1992). These "positively involved workers" (Aziz et al. 2010, p. 628), prototype of the ideal worker, spend a lot of time at work and think about it, but because working is a passion, by virtue of the enormous energy and positive affectivity that characterizes them. However, according to Aziz et al. (2010), both personal relationships and health can be harmed by excessive dedication to work. Additionally, they are "intrinsically and strongly motivated by loyalty, self-development and responsibility, and also, but to a lesser extent, by the level of their salaries" (Buelens and Poelmans 2004, p. 449). They are satisfied with the salary, the social relations, and did not intend to leave the organization. Although they do not report health complaints, they reported many conflicts between work and family.

Work Addicts-They have high scores on the dimensions of the scale of involvement with work and drive for work, and low scores on the dimension of pleasure from work (Spence and Robbins 1992). These workers spend too much time at work and thinking about it, maintaining a very unbalanced relationship between work and private life, despite work not being something they truly appreciate, they are perfectionists and have great difficulty in delegating tasks (Aziz et al. 2010). These workers report few sleeping hours and reduced free time. They have many conflicts at work and also family-work conflicts. Furthermore, they reveal dissatisfaction with salary, family, relationships.

Work Enthusiasts-those who achieve high scores on the scales of involvement and pleasure from work, and low scores on the drive to work (Spence and Robbins 1992). They are characterized as very hard-working, they like what they do, are always present and animated, and work long hours, even though the quality of their work is poor (Aziz et al. 2010). Enthusiastic workers are balanced people and have the ability to compensate in their physical and mental health for the effects of excess time spent at work-they also demonstrate a certain immunity to stress. Their high motivation seems to be stimulated "by all the factors that make people work harder, including money, responsibility, loyalty, and self-development" (Buelens and Poelmans 2004, p. 454).

Reluctant Hard Workers-This profile presents high scores in involvement dimension and low scores in drive and enjoyment dimensions of the workaholism scale (Spence and Robbins 1992). These workers reported relatively long working hours with a strong perception of pressure and a low perception of growth organizational culture. They intend to leave the organization, and are dissatisfied with the salary, the superior and even with their colleagues. 
Alienated Professional-These workers score below the mean on the scales of involvement, and above the mean on drive to work and enjoyment (Spence and Robbins 1992). They are internally driven and happy but not really committed with the work. This might be a group of professionals devoted to their professional skills, but not to their job or organization.

Disenchanted Workers-These workers score below the mean on the scales of involvement and pleasure with work, and above the mean on drive to work (Spence and Robbins 1992). Aziz et al. (2010) consider it to be the most problematic profile, due to they are extremely poor in satisfaction and in a sense of purpose, their psychological results are very poor, they experience high levels of stress and they are the ones who spend the least time at work. According to Buelens and Poelmans (2004), these workers are tremendously alienated, unmotivated and dissatisfied with their work in all aspects.

Relaxed Workers-They have low scores on the work engagement and work drive scales, and high on work pleasure (Spence and Robbins 1992). Unmotivated by salaries, they do not experience great pressure at work and manage to maintain a good relationship between work and family life. They are workers with high emotional well-being, they present only some complaints at the psychosomatic level (Aziz et al. 2010). Although they appreciate the challenges at work, they just don't get involved with it (Buelens and Poelmans 2004).

Unengaged Workers-This profile presents low scores in all dimensions of the workaholism scale (Spence and Robbins 1992). These workers do not have great motivation to work, being at the service strictly contracted hours. Their lives are not guided by great satisfaction or a sense of purpose, are accommodated to professional careers and are not subjected to great pressure at work (Aziz et al. 2010).

In Table 5 it is possible to analyze each typology profile of worker in our sample, attending to the cluster (low/high) in each WorkBat dimension. The largest number comprised the unengaged workers $(27.1 \%)$, followed in turn by disenchanted workers $(17.6 \%)$, alienated professionals $(16.7 \%)$, enthusiastic addicts $(12.4 \%)$, relaxed workers $(10.5 \%)$, work addicts $(8.5 \%)$, and, finally, by reluctant hard workers and work enthusiast (3.9\% and $3.3 \%$, respectively). Represent workaholic profiles $24.2 \%$ of the sample, composed of Enthusiastic addicts (12.4\%), Work addicts (8.5\%), and Work enthusiasts (3.3\%).

Table 5. Complete Spence and Robbins' typology (Spence and Robbins 1992) of worker profiles: samples' $n$ and \%.

\begin{tabular}{|c|c|c|c|c|c|}
\hline $\begin{array}{c}\text { WorkBat } \\
\text { Dimensions: }\end{array}$ & $\begin{array}{c}\text { Work } \\
\text { Involvement }\end{array}$ & Drive & $\begin{array}{c}\text { Enjoyment of } \\
\text { Work }\end{array}$ & Worker Profile & $n(\%)$ \\
\hline \multirow[t]{8}{*}{ Cluster: } & High & High & High & 1-Enthusiastic addicts & $38(12.4)$ \\
\hline & High & High & Low & 2-Work addicts & $26(8.5)$ \\
\hline & High & Low & High & 3-Work enthusiasts & $10(3.3)$ \\
\hline & High & Low & Low & 4-Reluctant hard worker & $12(3.9)$ \\
\hline & Low & High & High & 5-Alienated professional & $51(16.7)$ \\
\hline & Low & High & Low & 6-Disenchanted workers & $54(17.6)$ \\
\hline & Low & Low & High & 7-Relaxed Workers & $32(10.5)$ \\
\hline & Low & Low & Low & 8-Unengaged workers & $83(27.1)$ \\
\hline
\end{tabular}

Note: adapted from Buelens and Poelmans (2004), p. 444.

A MANOVA was conducted to test whether the profiles differ from each other regarding Workplace Spirituality dimensions. A significant multivariate effect was obtained, Pillai's Trace $=0.308, F(35,1490)=2.79, p<0.001$, observed power $=1.00, \eta^{2} p=0.065$ (multivariate effect size of $6.5 \%$ ). Univariate tests are displayed in Table 6. Workplace spirituality dimensions differed according to the worker profile (univariate effect sizes between $11 \%$ and $22 \%)$, excluding Opportunities for the inner life $(p=0.211)$. Enthusiastic addicts and work enthusiasts presented the highest workplace spirituality. Work enthusiastic scored the highest value in the Sense of enjoyment at work, and Reluctant hard workers score the lowest value in the Alignment between organizational and individual values. 
Table 6. Descriptive statistics (M; SD), Univariate tests $(F)$, effect size $\left(\eta^{2} p\right)$ and observed power $(1-\beta)$ of worker profiles.

\begin{tabular}{|c|c|c|c|c|c|c|c|c|c|c|c|c|c|c|c|c|c|c|c|}
\hline \multirow{2}{*}{ Worker Profile: } & \multicolumn{2}{|c|}{$\begin{array}{c}\text { Enthusiastic } \\
\text { Addicts }(n=38)\end{array}$} & \multicolumn{2}{|c|}{ Work Addicts $(n=26)$} & \multicolumn{2}{|c|}{ Work Enthusiast $(n=10)$} & \multicolumn{2}{|c|}{$\begin{array}{c}\text { Reluctant Hard Worker } \\
(n=12)\end{array}$} & \multicolumn{2}{|c|}{$\begin{array}{l}\text { Alienated Professional } \\
\quad(n=51)\end{array}$} & \multicolumn{2}{|c|}{$\begin{array}{c}\text { Disenchanted Worker } \\
(n=54)\end{array}$} & \multicolumn{2}{|c|}{ Relaxed Worker $(n=32)$} & \multicolumn{2}{|c|}{ Unengaged $(n=83)$} & \multirow{2}{*}{ F } & \multirow{2}{*}{$\eta p^{2}$} & \multirow{2}{*}{$\begin{array}{c}\text { Observed } \\
\text { Power }\end{array}$} \\
\hline & $M$ & $S D$ & $M$ & $S D$ & $M$ & $S D$ & $M$ & $S D$ & $M$ & $S D$ & $M$ & $S D$ & $M$ & $S D$ & $M$ & $S D$ & & & \\
\hline WS_TsenseCommunity & 4.73 & 0.92 & 4.16 & 1.55 & 4.5 & 1.2 & 3.63 & 1.32 & 4.34 & 0.86 & 3.68 & 0.93 & 4.42 & 0.85 & 3.85 & 1.08 & 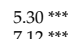 & 0.11 & 0.998 \\
\hline $\begin{array}{l}\text { WS_Aligment } \\
\text { WS senContribComun }\end{array}$ & $\begin{array}{l}4.80 \\
5.15\end{array}$ & $\begin{array}{l}0.86 \\
1.03\end{array}$ & $\begin{array}{l}4.21 \\
4.36\end{array}$ & $\begin{array}{l}1.27 \\
1.05\end{array}$ & 4.42 & $\begin{array}{l}1.18 \\
052\end{array}$ & $\begin{array}{l}3.58 \\
4.23 \\
-23\end{array}$ & $\begin{array}{l}1.31 \\
1.61\end{array}$ & $\begin{array}{l}4.46 \\
471\end{array}$ & $\begin{array}{l}0.7 \\
0.86\end{array}$ & $\begin{array}{l}3.82 \\
442\end{array}$ & $\begin{array}{l}0.94 \\
0.95\end{array}$ & $\begin{array}{l}4.25 \\
4.86\end{array}$ & $\begin{array}{l}0.76 \\
082\end{array}$ & $\begin{array}{l}3.74 \\
4.15\end{array}$ & $\begin{array}{l}1.02 \\
1.05\end{array}$ & 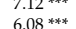 & 0.142 & 1.000 \\
\hline $\begin{array}{l}\text { WS__encontribComun } \\
\text { WS_senseJoy }\end{array}$ & $\begin{array}{l}5.15 \\
5.22\end{array}$ & $\begin{array}{l}1.103 \\
0.65\end{array}$ & $\begin{array}{l}4.36 \\
4.06\end{array}$ & $\begin{array}{l}1.05 \\
1.42\end{array}$ & $\begin{array}{l}5.1 \\
5.4\end{array}$ & $\begin{array}{l}0.022 \\
0.7\end{array}$ & $\begin{array}{l}4.23 \\
4.29\end{array}$ & $\begin{array}{l}1.1 .42 \\
1.42\end{array}$ & $\begin{array}{l}4.71 \\
4.89\end{array}$ & $\begin{array}{l}0.86 \\
0.7\end{array}$ & $\begin{array}{l}4.21 \\
4.11\end{array}$ & $\begin{array}{l}0.959 \\
0.79\end{array}$ & $\begin{array}{l}4.86 \\
4.89\end{array}$ & $\begin{array}{l}0.82 \\
0.66\end{array}$ & 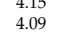 & $\begin{array}{l}1.05 \\
1.01\end{array}$ & 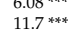 & $\begin{array}{l}0.22 \\
0.22\end{array}$ & $\begin{array}{l}1.0000 \\
1.000\end{array}$ \\
\hline WS_OppInnerLife & 4.55 & 1.33 & 4.12 & 1.5 & 4.3 & 1.32 & 3.88 & 1.54 & 4.38 & 1.1 & 4.11 & 1.1 & 4.58 & 1.22 & 4.01 & 1.33 & 1.38 & 0.03 & 0.586 \\
\hline
\end{tabular}


Post-hoc Bonferroni tests were performed to examine the profiles' mean differences regarding the Workplace Spirituality (see Table 7 for significant mean differences). Regarding the Sense of community dimension, the biggest difference concerns the Enthusiastic addicts and Reluctant hard Worker profiles and the smallest difference concerns the Alienated professional and Disenchanted workers profiles, with a value of mean difference of 0.663 . Regarding the Alignment dimension, the biggest difference concerns the Enthusiastic addicts and Reluctant hard Worker profiles and the Enthusiastic addicts and Unengaged workers. The smallest difference concerns the Alienated professional and Disenchanted workers profiles. Regarding the Sense of Contribution to Community dimension, the biggest difference concerns the Enthusiastic addicts and Unengaged workers profiles. The smallest difference concerns the Alienated professional and Unengaged workers profiles, with a value of mean difference of 0.558 . Finally, regarding the Sense of enjoyment at work dimension, the biggest differences concern the Work Enthusiast and Work Addicts, and the Work Enthusiast and Disenchanted workers. The smallest difference concerns the Relaxed Workers and Disenchanted workers profiles.

Table 7. Workplace Spirituality means difference of each profile and multiple comparison tests between profiles.

\begin{tabular}{|c|c|c|c|c|}
\hline Dependent Variable (WS Dimension) & Profiles & Mean Difference & SE & $p$ \\
\hline \multirow{5}{*}{$\begin{array}{l}\text { Alignment between organizational and } \\
\text { individual values } \\
\text { (WS_senseCommunity) }\end{array}$} & Enthusiastic addicts-Reluctant hard Worker & 1.096 & 0.346 & 0.047 \\
\hline & Enthusiastic addicts-Disenchanted workers & 1.050 & 0.221 & 0.000 \\
\hline & Enthusiastic addicts-Unengaged workers & 0.878 & 0.204 & 0.001 \\
\hline & Alienated professional-Disenchanted workers & 0.663 & 0.204 & 0.036 \\
\hline & Relaxed Workers-Disenchanted workers & 0.746 & 0.233 & 0.042 \\
\hline \multirow{5}{*}{$\begin{array}{l}\text { Alignment between organizational and } \\
\text { individual values (WS_Aligment) }\end{array}$} & Enthusiastic addicts-Reluctant hard Worker & 1.218 & 0.317 & 0.004 \\
\hline & Enthusiastic addicts-Disenchanted workers & 0.986 & 0.203 & 0.000 \\
\hline & Enthusiastic addicts-Unengaged workers & 1.060 & 0.187 & 0.000 \\
\hline & Alienated professional—Disenchanted workers & 0.647 & 0.187 & 0.017 \\
\hline & Alienated professional-Unengaged workers & 0.721 & 0.17 & 0.001 \\
\hline \multirow{4}{*}{$\begin{array}{l}\text { Sense of contribution to the community } \\
\text { (WS_senContribComun) }\end{array}$} & Enthusiastic addicts-Disenchanted workers & 0.939 & 0.21 & 0.000 \\
\hline & Enthusiastic addicts-Unengaged workers & 0.995 & 0.195 & 0.000 \\
\hline & Alienated professional-Unengaged workers & 0.558 & 0.177 & 0.049 \\
\hline & Relaxed Workers-Unengaged workers & 0.71 & 0.207 & 0.019 \\
\hline \multirow{11}{*}{$\begin{array}{l}\text { Sense of enjoyment at work } \\
\text { (WS_senseJoy) }\end{array}$} & Enthusiastic addicts—Work Addicts & 1.166 & 0.232 & 0.000 \\
\hline & Enthusiastic addicts-Disenchanted workers & 1.113 & 0.139 & 0.000 \\
\hline & Enthusiastic addicts_-Unengaged workers & 1.133 & 0.179 & 0.000 \\
\hline & Work Enthusiast-Work Addicts & 1.342 & 0.340 & 0.003 \\
\hline & Work Enthusiast-Disenchanted workers & 1.289 & 0.314 & 0.001 \\
\hline & Work Enthusiast-Unengaged workers & 1.310 & 0.305 & 0.001 \\
\hline & Alienated professional-Work Addicts & 0.834 & 0.220 & 0.005 \\
\hline & Alienated professional-Disenchanted workers & 0.781 & 0.178 & 0.000 \\
\hline & Alienated professional—Unengaged workers & 0.802 & 0.162 & 0.000 \\
\hline & Relaxed workers-Work Addicts & 0.833 & 0.241 & 0.017 \\
\hline & Relaxed Workers-Disenchanted workers & 0.780 & 0.204 & 0.004 \\
\hline
\end{tabular}

Figure 1 represents how the individuals perceive Workplace Spirituality in each worker profile, regarding the six workplace spirituality dimensions. In order to make it easier to perceive the differences among the profiles, standardized scores were used, based on the means of each workplace spirituality dimension. As we can see, Enthusiastic addicts and Work enthusiasts present the highest scores, contrasting mainly with Reluctant hard worker, Disenchanted workers, and Unengaged workers. 


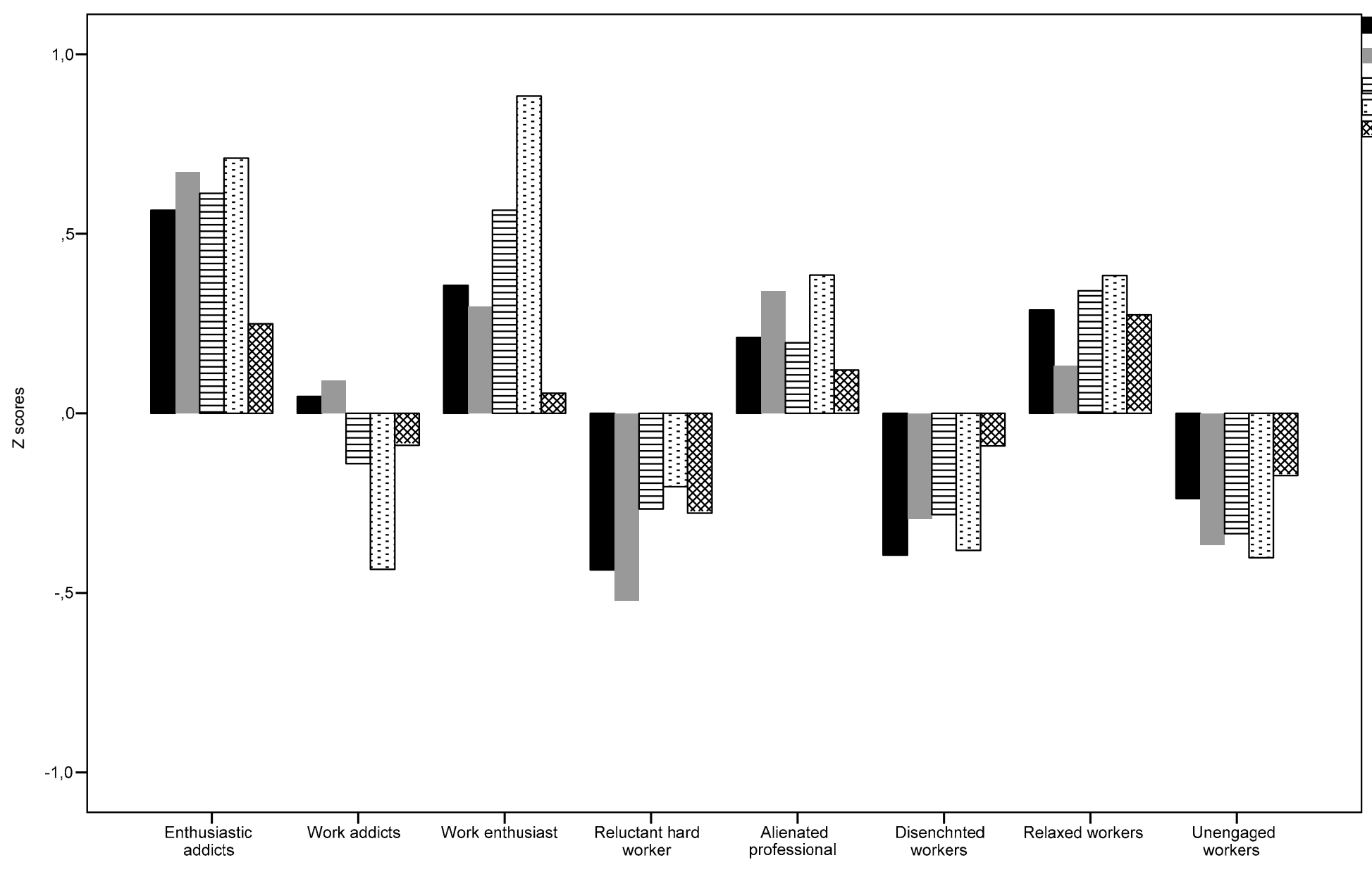

Sense of community

Alignment between organizational and individual

Sense of contribution to the community

Sense of enjoyment at work

Opportunities for the inner life

Figure 1. Workplace Spirituality dimensions in each worker profile: standardized scores. 


\section{Dicussion}

The main objective of the article was to provide a better understanding of the study of workaholism, namely on the different profiles of workers and their respective relationships with the dimensions of the workplace spirituality. It was possible to observe that there is a low and positive relationship between the global scale of workplace spirituality and the workaholism dimensions Work Involvement and Drive, although a moderate relationship with Enjoyment of work. Assuming that spirituality is an internal resource that individuals can turn to, it is possible to assume that the higher the levels of workplace spirituality, the greater the probability of developing some worker profile involving a high Enjoyment of work (Enthusiastic addicts, Work enthusiasts, Alienated professional, or Relaxed Workers, according to Spence and Robbins' typology).

The results are in line with other studies carried out in Portugal (e.g., Pedreira and Mónico 2013). However, is pertinent to highlight the two other dimensions of WorkBat, and also other measures of workaholism. Indeed, some literature reveals a distinct approach. Spirituality can be understood as a resource to combat negative habits, reduce stress, contribute to general well-being (Goltz 2011), increase organizational commitment (Vandenberghe 2011), inspire greater performance (Smith and Futrell 2014), and allay the negative consequences of workaholism (Saxton 2016). Organizational climate, productivity/performance, commitment, trust, emotional intelligence, psychological capital, among other variables, have also been positively associated with workplace spirituality (e.g., Krishnakumar and Neck 2002; Mónico et al. 2016; Pedreira and Mónico 2013; Rego et al. 2007).

Considered as ideal and positively involved workers, addicted enthusiasts and enthusiastic workers, characterized by their balance between physical and mental health and work, are the groups that present the highest levels of workplace spirituality. The results are corroborated by the work of Rust and Gabriels (2011), when they state that when there is harmony between the company and the integration of employees' personal values (e.g., spirituality), everyone can aspire to greater things. Accordingly, as pointed out by Preziosi and Marschke (2011), the world of work in the 21st century wants to prosper more and more and, therefore, there is a need for both organizational leaders and their employees to use the spiritual resources, due to it will also make a significant contribution to society at large.

The cluster analysis allowed us to verify that it is the work enthusiast group who score the highest in the sense of pleasure and enjoyment at work. This result is consistent with the literature (e.g., Buelens and Poelmans 2004), which states that work enthusiasts are happy workers, love their jobs and avoid conflict both at workplace and at home. These behaviors can be related to the fact that they have a positive mindset, high levels of social intelligence (Buelens and Poelmans 2004) and the possibility of living their spirituality in the workplace. In addition to improving employee performance, as well as well-being and quality of life, through reducing stress, burnout and workaholism (Karakas 2010), spirituality catapults organizational effectiveness by providing employees with a sense of interconnectedness and community.

In contrast, it is the reluctant hard worker (those whose perception of organizational growth is low), the disenchanted worker (characterized by the alienation, lack of motivation and dissatisfaction with work at various levels) and the unengaged worker (lack of a sense of purpose, accommodated to their careers), who have lower levels of spirituality. It is worth emphasizing the finding of Killinger (2006), who states that the stress caused by workaholism can lead to loss of spirituality, chronic diseases, pain, and guilt.

\section{Conclusions}

This research contributed to the literature on workaholism by creating a analyze model of a workaholic and non-workaholic worker profiles, and studying the relationships with workplace spirituality. The literature points out that workplace spirituality has gained increasing attention in the organizational research field, considering this dimension a 
multidimensional construct and an alternative to improve employees' general well-being (e.g., Kinjerski 2013; McKee et al. 2011). Workaholism is a complex and multidimensional phenomenon, whose dimensions are distinctly related to workplace spirituality. Hence, workplace spirituality development can promote a more balanced and healthy relationship with work. This study also made it possible to understand how a soft skill, such as spirituality, can be a core value influence the development of a particular worker profile.

Workplace spirituality is associated with the inner life of employees, the connection with others, and the search for meaningful work in the community. In this way, when find a purpose in the professional activities, they act in an engaged way, applying the potential for the benefit of the organization. In addition to making them more productive over time, the incorporation of this value in organizations can influence the reduction of workaholic profiles and, consequently, the phenomenon of sustainability (Rezapouraghdam et al. 2019). On the one hand the Covid-19 pandemic led to job losses, influencing the increase in symptoms such as stress, depression and substance abuse, on the other hand it masked the boundaries between professional and family life, with the introduction of the concept 'working from home'. Therefore, the role of workplace spirituality is relevant, because it can play a vital role in improving mental well-being when it is properly accepted and practiced in organizations (Hisam and Sanyal 2021). Twenty-first century employees, despite following the various changes in the world of work (e.g., technology), seek and need a professional context that allows them to find a sense of purpose in harmony with the internal and personal values (Abdul Latiff 2021). In an organization that excels and respects the value of spirituality (of each one) it allows shaping behavior and professional performance, improving productivity and reducing addictive behaviors.

From a practical and professional point of view, our results can be particularly useful in the design of workshop on this topic. Spiritual workplaces encourage employees' sense of community, foster feelings of engaging in meaningful work, and support integrity, respect, responsibility, and personal/individual growth (e.g., Giacalone and Jurkiewicz 2003; Dhiman and Marques 2010; Kinjerski 2013). This type of initiative can allow organizations that adhere to the spiritual mindset to be more successful, ensure the happiness of the employees and are even more aware of their environmental and sustainable responsibilities. The findings reinforce the importance of the role of universities in improving the offer of programs that foster not only the economic aspect of entering the labor market, but also the importance of the idiosyncrasies of workers. Thus, policy makers and institutions responsible for creating labor-market orientations programs, should pay more attention and bring personal values to traditional training and education.

The present article has some limitations that should be addressed in future studies. The variables used in this study allowed us analyze the workaholism profiles and the relationships with the workplace spirituality dimensions of Portuguese workers. Although we strongly believe that these outputs are positive and promising, it is important to introduce new variables, measures, and theories that allow drawing a more consistent model. Regarding the sample, we consider that in the future it may be extended to other countries to evaluate cultural differences, which would permit to observe a broader range of results. For a better evaluation of the worker profiles it would be important to consider a longitudinal research to better understand the constructs' dynamic.

Author Contributions: Conceptualization, L.S.M. and C.M.; methodology: L.S.M.; software, C.M. and L.S.M.; formal analysis, L.S.M.; writing-original draft preparation and editing, C.M. All authors have read and agreed to the published version of the manuscript.

Funding: This research received no external funding.

Institutional Review Board Statement: Not applicable.

Informed Consent Statement: Informed consent was obtained from all subjects involved in the study. 
Data Availability Statement: The data presented in this study are available on request from the first author, e-mail: lisete.monico@fpce.uc.pt.

Conflicts of Interest: The authors declare no conflict of interest.

\section{References}

Abdul Latiff, Noraidah. 2021. The Effect of Workplace Spirituality on Employee Performance. Issues and Perspectives in Business and Social Sciences 1: 22-27. [CrossRef]

Afsar, Bilal, and Yuosre Badir. 2017. Workplace spirituality, perceived organizational support and innovative work behavior: The mediating effects of person-organization fit. Journal of Workplace Learning 29: 95-109. [CrossRef]

Andreassen, Cecile, Jørn Hetland, and Ståle Pallesen. 2010. The Relationship between workaholism: Basic needs satisfaction at work and personality. European Journal of Personality 24: 3-17. [CrossRef]

Atroszko, Pawel, Zsolt Demetrovics, and Mark Griffiths. 2019. Beyond the myths about work addiction: Toward a consensus on definition and trajectories for future studies on problematic overworking. Journal of Behavioral Addiction 8: 7-15. [CrossRef]

Aziz, Shahnaz, and Casie Tronzo. 2011. Exploring the relationship between workaholism facets and personality traits: A replication in American workers. The Psychological Record 61: 269-86. [CrossRef]

Aziz, Shahnaz, Karl Wuensch, and Howard Brandon. 2010. A Comparison among worker types using a composites approach and median splits. The Psychological Record 60: 627-42. [CrossRef]

Balducci, Cristian, Lorenzo Avanzi, and Franco Fraccaroli. 2018. The Individual "Costs" of Workaholism: An Analysis Based on Multisource and Prospective Data. Journal of Management 44: 2961-86. [CrossRef]

Balducci, Cristian, Paola Spagnoli, and Melisa Clark. 2020a. Advancing Workaholism Research. International Journal of Environmental Research and Public Health 17: 9435. [CrossRef]

Balducci, Cristian, Guido Alessandri, Sara Zaniboni, Lorenzo Avanzi, Aura Borgogni, and Franco Fraccaroli. 2020b. The impact of workaholism on day-level workload and emotional exhaustion, and on longer-term job performance. Work $\mathcal{E}$ Stress 35: 6-26. [CrossRef]

Bella, Rircardo, Osvaldo Quelhas, Fernando Ferraz, and Marlene Bezerra. 2018. Workplace Spirituality: Sustainable Work Experience from a Human Factors Perspective. Sustainability 10: 1887. [CrossRef]

Bickerton, Grant, Maureen Miner, Martin Dowson, and Barbara Griffin. 2015. Incremental validity of spiritual resources in the job demands-resources model. Psychology of Religion and Spirituality 7: 162-72. [CrossRef]

Bollen, Kenneth. 1989. Structural Equations with Latent Variables. New York: John Wiley \& Sons.

Buelens, Mark, and Steven Poelmans. 2004. Enriching the Spence and Robbins' typology of workaholism: Demographic, motivational and organizational correlates. Journal of Organizational Change Management 17: 440-58. [CrossRef]

Clark, Melissa, Jesse Michel, Ludmila Zhdanova, Shuang Pui, and Boris Balts. 2016. All work and no play? A meta-analytic examination of the correlates and outcomes of workaholism. Journal of Management 42: 1836-73. [CrossRef]

Clark, Melissa, Rachel Smith, and Nicholas Haynes. 2020. The Multidimensional Workaholism Scale: Linking the conceptualization and measurement of workaholism. Journal of Applied Psychology 105: 1281-307. [CrossRef] [PubMed]

Cohen, Jacob. 1988. Statistical Power Analysis for the Behavioral Sciences. New York: Routledge Academic.

Cristão, Catarina. 2010. Cerca de 10\% dos portugueses são viciados no trabalho. Diário de Notícias, (Online). Available online: http:/ / www.dn.pt/inicio/ciencia/interior.aspx?content_id=1547056\&seccao=Sa\%FAde (accessed on 21 April 2021).

Dhiman, Satinder, and Joan Marques. 2010. The role and need of offering workshops and courses on workplace spirituality. Journal of Management Development 30: 816-35. [CrossRef]

Dhiman, Satinder, and Joan Marques. 2016. Spirituality and Sustainability. Cham: Springer.

Duchon, Dennis, and Donde Plowma. 2005. Nurturing the spirit at work: Impact on work unit performance. The Leadership Quarterly 16: 807-33. [CrossRef]

Fairholm, Gilbert. 1996. Spiritual leadership: Fulfilling whole-self needs at work. Leadership E Organization Development Journal 17: 11-17.

Foster, Scott, and Anna Foster. 2019. The impact of workplace spirituality on work-based learners: Individual and organizational level perspectives. Journal of Work-Applied Management 11: 63-75. [CrossRef]

Fry, Louis. 2003. Toward a theory of spiritual leadership. The Leadership Quarterly 14: 693-727. [CrossRef]

Garg, Naval. 2017. Workplace Spirituality and Employee well-being: An empirical exploration. Journal of Human Values 23: $129-47$. [CrossRef]

Gelbard, Roy, Orit Goldman, and Israel Spiegler. 2007. Investigating diversity of clustering methods: An empirical comparison. Data and Knowledge Engineering 63: 155-66. [CrossRef]

Giacalone, Robert, and Carole Jurkiewicz. 2003. Right from wrong: the influence of spirituality on perceptions of unethical business activities. Journal of Business Ethics 46: 85-97. [CrossRef]

Goltz, Sonia. 2011. Spiritual power: The internal, renewable social power source. Journal of Management, Spirituality $\mathcal{E}$ Religion 8: 341-63. [CrossRef]

Griffiths, Mark. 2005. Workaholism is still a useful construct. Addiction Research and Theory 13: 97-100. [CrossRef]

Hair, Joseph, William Black, Barry Babin, and Rolph Anderson. 2018. Multivariate Data Analysis, 7th ed. Hoboken: Pearson Prentice-Hall. 
Hisam, Mohammed, and Shouvik Sanyal. 2021. Impact of workplace spirituality on organizational commitment-a study in an emerging economy. Turkish Journal of Computer and Mathematic Education 12: 984-1000. [CrossRef]

IBM Corp. 2013. IBM SPSS Statistics for Windows, Version 22.0. Armonk: IBM Corp.

Karakas, Fahri. 2010. Spirituality and Performance in Organizations: A literature review. Journal of Business Ethics 94: 89-106. [CrossRef]

Kent, Peter, Rikkle Jensen, and Alice Kongsted. 2014. A comparison of three clustering methods for finding subgroups in MRI, SMS or clinical data: SPSS twostep cluster analysis, latent Gold and SNOB. BMC Medical Research Methodology 14: 113. [CrossRef]

Killinger, Barbara. 2006. The Workaholic Breakdown Syndrome. In Research Companion to Working Time and Work Addiction. Edited by Ronald Burke. Cornwall: Elward Elgar, pp. 61-88.

Kinjerski, Val. 2013. The spirit at work scale: Developing and validating a measure of individual spirituality at work. In Handbook of Faith and Spirituality in the Workplace. Edited by Judy Neal. New York: Springer, pp. 340-83.

Kline, Rex. 2011. Principles and Practice of Structural Equation Modeling, 3rd ed. New York: The Guilford Press.

Kolodinsky, Robert, Robert Giacalone, and Carole Jurkiewicz. 2008. Workplace values and outcomes: Exploring personal, organizational and interactive workplace spirituality. Journal of Business Ethics 81: 465-80. [CrossRef]

Krishnakumar, Sukumarakurup, and Christopher Neck. 2002. The "what". "why" and "how" of spirituality in the workplace. Journal of Managerial Psychology 17: 153-64. [CrossRef]

Marques, Joan, Satinder Dhiman, and Richard King. 2005. Spirituality in the workplace: Developing an integral model and a comprehensive definition. Journal of the American Academy of Business 7: 81-91.

McKee, Margaret, Cathy Driscoll, E. Kevin Kelloway, and Elizabeth Kelle. 2011. Exploring linkages among transformational leadership, workplace spirituality and well-being in health care workers. Journal of Management, Spirituality E Religion 8: 233-55. [CrossRef]

Molino, Monica, Emanuela Ingusci, Fulvio Signore, Amelia Manuti, Maria Luisa Giancaspro, Vincenzo Russo, Margherita Zito, and Claudio Cortese. 2020. Wellbeing costs of technology use during covid-19 remote working: An investigation using the italian translation of the Technostress Creators Scale. Sustainability 12: 5911. [CrossRef]

Mónico, Lisete, Nathalia Mellão, Luiza Nobre-Lima, Pedro Parreira, and Carla Carvalho. 2016. Emotional intelligence and psychological capital: What is the role of workplace spirituality? Revista Portuguesa de Enfermagem e Saúde Mental 3: 45-50. [CrossRef]

Murray, Margaret, and Frederick Evers. 2011. Reweaving the fabric: Leadership and spirituality in the 21st Century. Interbeing 5: 5-15.

Myers, Jane, and Kirk Williard. 2003. Integrating spirituality into counselor preparation: A developmental, wellness approach. Counseling and Values 47: 142. [CrossRef]

$\mathrm{Ng}$, Thomas, Kelly Sorensen, and Daniel Feldman. 2007. Dimensions, antecedents, and consequences of workaholism: A conceptual integration and extension. Journal of Organizational Behavior 28: 111-36. [CrossRef]

Nunnally, Jum, and Ira Bernstein. 1994. Psychometric theory. New York: McGraw-Hill.

Oates, Wayne. 1971. Confessions of a Workaholic: The Facts about Work Addiction. New York: World Publishing.

Oman, Doug. 2015. Defining Religion and Spirituality. In Handbook of the Psychology of Religion and Spirituality. Edited by Raymond Paloutzian and Crystal Park. New York: The Guilford Press, pp. 23-47.

Ornek, Ozlem, and Nurcan Kolac. 2020. Quality of Life in Employee with Workaholism. In Occupational Health. Edited by Orhan Korhan. London: IntechOpen, Available online: https:/ / www.intechopen.com/online-first/quality-of-life-in-employee-withworkaholism (accessed on 21 April 2021). [CrossRef]

Pawar, Badrinarayan. 2016. Workplace spirituality and employee well-being: An empirical examination. Employee Relations 38: 975-94. [CrossRef]

Pedreira, Luanda, and Lisete Mónico. 2013. Workaholism and Psychological Capital: Repercussions on workplace spirituality. International Journal of Developmental end Educational Psychology 2: 535-44.

Porter, Gayle. 1996. Organizational impact of workaholism: Suggestions for researching the negative outcomes of excessive work. Journal of Occupational Health Psychology 1: 70-84. [CrossRef]

Preziosi, Robert, and Eleanor Marschke. 2011. How sales personnel view the relationship between satisfaction and spirituality in the workplace. Journal of Organizational Culture, Communications and Conflict 15: 71-110.

Rahman, Muhammad, Mahmud Zaman, Md Afan Hossain, Mahafuz Mannan, and Hasliza Hassan. 2019. Mediating effect of employee's commitment on workplace spirituality and executive's sales performance: An empirical investigation. Journal of Islamic Marketing 10: 1057-73. [CrossRef]

Rego, Arménio, and Miguel Pina e Cunha. 2008. Workplace spirituality and organizational commitment: An empirical study. Journal of Organizational Change Management 21: 53-75. [CrossRef]

Rego, Arménio, S. Souto, and Miguel Pina Cunha. 2007. Espiritualidade nas organizações positividade e desempenho. Comportamento Organizacional e Gestão 13: 7-36.

Rezapouraghdam, Hamed, Habib Alipour, and Huseyin Arasli. 2019. Workplace spirituality and organization sustainability: A theoretical perspective on hospitality employees' sustainable behavior. Environment, Development and Sustainability 21: 1583-601. [CrossRef]

Roof, Richard. 2015. The association of individual spirituality on employee engagement: The spirit at work. Journal of Business Ethics 130: 585-99. [CrossRef]

Rust, Braam, and Cecilia Gabriels. 2011. Spirituality in the workplace: Awareness of the human resource function. African Journal of Business Management 5: 1353-64. 
Samah, Siti, Abu Silong, Kamaruzaman Jusoff, and Ismi Ismail. 2012. Relationship between spirituality and academic leader effectiveness. International Conference on Human and Social Sciences 2: 33.

Saxton, Michael. 2016. Workplace Spirituality, Workaholism, and Gender: A Quantitative Study of Higher Education Employees at a Small, Private College in the Northeastern United States. Ph.D. thesis, Capella University, Minneapolis, MN, USA.

Schaufeli, Wilmar, Toon Taris, and Willem van Rhenen. 2008. Workaholism, burnout, and work engage-ment: Three of a kind or three different kinds of employee well-being? Applied Psychology 57: 173-203. [CrossRef]

Schumacker, Randall, and Richard Lomax. 2016. A Beginner's Guide to Structural Equation Modeling, 4th ed. New York: Routledge.

Smith, Garry, and Charles Futrell. 2014. The inspired salesperson: Linking spirituality to performance. Marketing Management Journal 24: 172-85. [CrossRef]

Spagnoli, Paola, and Danila Molinaro. 2020. Negative (Workaholic) Emotions and Emotional Exhaustion: Might job autonomy have played a strategic role in workers with responsibility during the Covid-19 crisis lockdown? Behavioral Sciences 10: 192. [CrossRef]

Spence, Janet, and Ann Robbins. 1992. Workaholism: Definition. Measurement. And Preliminary Results. Journal of Personality Assessment 58: 160-78. [CrossRef] [PubMed]

Stahl, Ashley. 2019. Millenials: The Most Unhealthy Generation at Work. Forbes (Online). Available online: https://www.forbes. $\mathrm{com} /$ sites/ashleystahl/2020/12/30/millennials-the-most-unhealthy-generation-at-work/?sh=70be717d7b12 (accessed on 21 April 2021).

Stoeber, Jachim, and Lavinia Damian. 2016. Perfectionism in Employees: Work engagement, workaholism, and burnout. In Perfectionism, Health, and Well-Being. Edited by Fuschia Sirois and Danielle Molnar. New York: Springer, pp. 265-83.

Subramanian, Kalpathy. 2018. Workaholism-Does working more impact productivity? International Journal of Innovative Trends in Engineering 40: 69-75.

Tabachnick, Barbara, and Linda Fidell. 2007. Using Multivariate Statistics. Boston: Pearson Education, Inc.

Tepper, Bennet. 2003. Organizational citizenship behavior and the spiritual employee. In Handbook of Workplace Spirituality and Organizational Performance. Edited by Robert Giacalone and Carole Jurkiewicz. New York: M.E. Sharpe, pp. 181-90.

Urbina, Susana. 2014. Essentials of Psychological Testing. Hoboken: Wiley.

van der Walt, Freda, and Jeremias de Klerk. 2014. Workplace spirituality and job satisfaction. International Review of Psychiatry 26: 379-89. [CrossRef] [PubMed]

Vandenberghe, Christian. 2011. Workplace spirituality and organizational commitment: An integrative model. Journal of Management, Spirituality \& Religion 8: 211-32. [CrossRef]

Vyas, Lina, and Nantapong Butakhieo. 2020. The impact of working from home during the COVID-19 on work and life domains: An exploratory study on Hong Kong. Policy, Design and Practice 4: 59-76. [CrossRef]

Wall, Tony, and John Knights. 2013. Leadership Assessment for Talent Development. London: Kogan.

Zsolnai, Laszlo, and Katalin Illes. 2017. Spiritually-inspired creativity in business. International Journal of Social Economics 44: 195-205. [CrossRef] 